\title{
CONCEPT AND PHYSICAL CHARACTERISTICS OF CAPSULE ARCHITECTURE
} カプセル建築における設計主題と実体的特徵

\author{
Volodymyr DEREZNICHENKO ${ }^{* 1}$ and Taishin SHIOZAKI ${ }^{* 2}$ \\ ヴォロディーミル デレズニチェンコ, 塩 崎 太伸
}

This paper highlights the typology of capsule architecture by studying its concept and basic characteristics of capsules. This is done by sorting out and analyzing examples of capsule architecture through the prototype stage in the early 20th century, full development in the 1960s, and reappearance in modern days. The study introduces three categories of so-called mental capsules, mobile capsules, and growing capsules. Research also analyzes shapes, functions, materials, size, number of capsules, and methods of their arrangement. The paper in overall highlights the potential and usefulness of capsular designs over conventional architecture.

Keywords : Capsule architecture, Residential units, Modular architecture, Metabolism, Archigram, Megastructures カプセル建築，住宅ユニット，モジュラー建築，メタボリズム，アーキグラム，メガストラクチャ

1. Introduction

1. 1 Revisiting the notion of capsule architecture

Stimulus for this research was an investigation following the case of Nakagin Capsule Tower (Fig.1). This building is a representative of Metabolism architectural movement from Japan in 1960-1970s and, so-called, capsule architecture - the architectural typology of buildings consisting of repeating spatial blocks, that is, capsules ${ }^{1)}$. The tower was envisioned as constantly changing entity which shape and lifespan may be prolonged due to manipulation of capsules. Yet, such manipulation has never occurred. Senk points out an outdated role of a capsule in relation to megastructures ${ }^{* 1)}$ being envisioned as future endless cities $^{* 2}$. Lin and Hosoya also mention a continuous urban metabolism and fluctuations in land prices what makes a long-time planning of capsular buildings unfeasible ${ }^{2), 3)}$, whilst Sugai and Yokota refer to the intention of Kurokawa to realize a working prototype of Metabolist in the building what leaded to actual limitation of possible renovation approaches ${ }^{4}$.

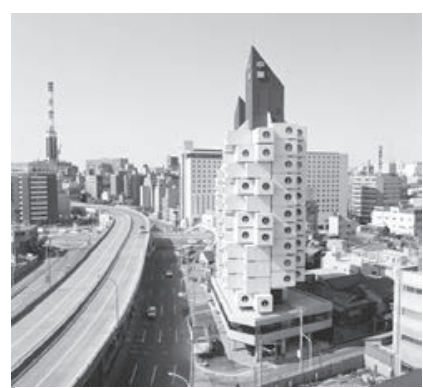

Fig. 1 Nakagin Capsule Tower, Kisho Kurokawa, 1972

Deviation of capsule architecture from ordinary buildings originates from modernist architectural practices. Metabolism as the last of movements with their own manifesos ${ }^{5)}$, was similarly influenced by drastic changes in the $20^{\text {th }}$ century and common cultural change to the new type of society, probably, the one radical enough to accept capsules as a part of the celebration of the brave new world. Nakagin Capsule Tower was similarly provided for, how Kurokawa himself puts it, 'homo-movens'b) but nowadays the capsules became both investment and bill to vote for the building's fate ${ }^{7}$. Such social turnover becomes native to modern architectural paradigms and is often combined with the notion of 'sustainability'. Or, how Schalk states, revisiting Metabolism have a key to understand the modern inquiry of sustainability usually presented ahistorically ${ }^{8}$. Russel also highlights the dilemma of Metabolists seeking to shift from mechanical mode ${ }^{9)}$ to the buildings evolving as a living organism ${ }^{10)}$ while Olivera mentions the 'collectibe willpower of the $60 \mathrm{~s}^{\text {'11) }}$ what can resonance today in order to foster a harmonic relationship between a man and environment ${ }^{12}$ ). Senk also mentions capsule typology as architecture of resistance against conformity 'between institutions and living environments', as well as freedom from the fear of imagining

\footnotetext{
"1 Graduate Student, Dept. of Architecture and Building Engineering, Tokyo Institute of Technology, M.Eng.

2 Assoc. Prof., Dept. of Architecture and Building Engineering,

東京工業大学環境 · 社会理工学院建築学系 博士課程 · 修士 (工学)

Tokyo Institute of Technology, Dr.Eng.
} 
alternative possibilities in architecture for better future. Thus, some new kinds of capsules are being created again as if updated versions of their predecessors from the $60 \mathrm{~s}$ as acceptance of change and importance of the role of technology in construction of cities ${ }^{13)}$. One of such modern formations is a shipping container ${ }^{* 3}$, while capsule hotels in a recent decade has become popular outside Japan and brought in a new trend of capsular interior spaces. These new capsules tend to be more self-sustaining, and sometimes, stereotypically, bear solar panels on their roofs and enhance a meaning of urban nomadism.

\section{2 Aim of research}

Architectural movements from the 1960s as Metabolism or Archigram viewed a capsule as a powerful architectural tool to redefine home and to put new principles of functionalism into practice. However, nowadays the designs utilizing capsules and modular elements appear frequently again. Moreover, the interpretation of a capsule has expanded and nowadays it is highly influenced by trends of green technology and sustainability. Thus, the research, aims to create a comprehensive view onto the typology of capsule architecture and put its various examples on a timescale. By doing this, the research seeks to reinforce a connection between original capsules from 1960s and modern designs to trace the transition of their capacities. The research analyses both capsular buildings and single capsules and treats both as an independent object inside a bigger urban realm (Fig. 5).

\section{3 Explanation of gathered data}

Data for the research is not restricted by time or place and represents a set of cases of capsule architecture and related cases falling under the designation of a capsule based by Senk's description (see Chapter 2). Moreover, separate cases of capsule hotels and container architecture are also included. The gathered cases also include unrealized projects. That is done due to a significant number of unbuilt projects, which bear notable ideas about possibilities of using capsules. Aiming to create a broad view onto capsule architecture, this research includes 265 cases in total with 115 unbuilt and 150 built examples. The sources for data contains explanation of basic properties of a given example as physical characteristics, function, relation to a core structure, the basic idea applied to a building's design and usage of capsules. The primary sources for data searching include papers of previous studies (as Senk, Hidaka, Ishida), books (as Koolhaas, Dehindem, Kurokawa), periodicals (as Shinkenchiku, SD, A+U), Internet journals (as Archdaily, Architectural Review, Dezeen, Weburbanist, Wikiarquitectura), Internet portals (as Astudejaoublie, Bubblemania.fr, FRAC Centre-Val De Loire, Hidden Architecture, Spatial Agency, The Archigram Archival Project, The Buckminster Fuller Institute). The case study example is shown in Fig. 2.

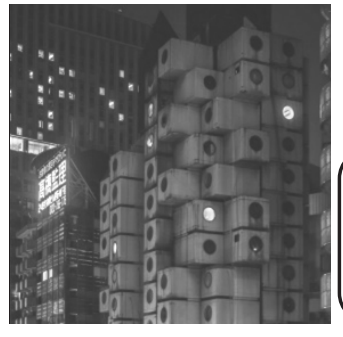

\begin{tabular}{ll} 
No. & 87 \\
$\frac{\text { Name }}{\text { Year }}$ & Nakagin Capsule Tower \\
\hline Architect/Bureau & 1972 \\
\hline Country/Region & Kisho Kurokawa \\
Sapan/Asia \\
Status & Concept/Built/Being renovated \\
Way of arrangement & Method (3), Plug-in \\
No. of capsules & 140 \\
Shape & Rectangular \\
Function & Multipurpose \\
Materials & Steel/Metal frame \\
Capsule size fit inside & $4 \mathrm{~m}^{3}$ cube
\end{tabular}

Chapter 3

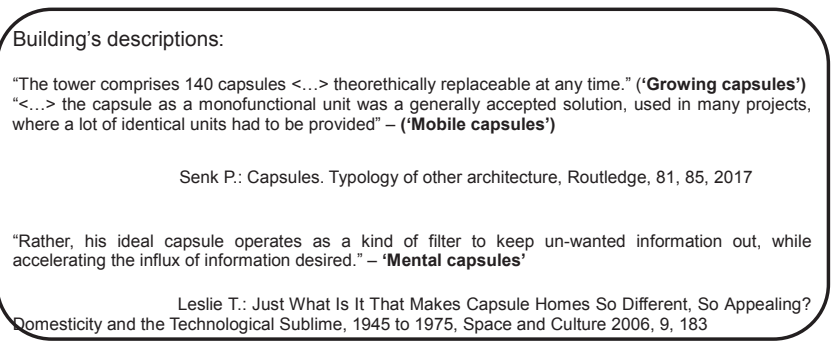
omesticity and the Technological Sublime, 1945 to 1975 , Space and Culture 2006, 9, 183

Fig. 2 Case study example

\section{4 Methodology of research}

The analysis applied in this research consists of collecting the data and its classification. First, the selected examples are put onto the timeline in order to observe the distribution of the cases. This research also thoroughly explains application of the concept of a capsule and solidifies a vague figure of capsule architecture among other existing architectural typologies. This is done by grouping the common notions provided by architects in their interviews or texts of how they primarily use the capsules for. Similar ideas and approaches are grouped further in order to extract common trends. Again, the data is sorted and organized by the year of design (or construction), their affiliation to either built or unbuilt category, characteristics of capsules used in a given structure and type of relationship between capsules and a structure. This, in general, will facilitate the deeper understanding of common applications of capsules and their primary parameters. The whole data is summarized in Appendix 1.

\section{Concept of capsule architecture}

2. 1 Historical development of capsule architecture

All studied modern and historical examples of capsule architecture are put over the timeline and divided into built and unbuilt categories 
(Fig. 3). The main feature here is two spikes corresponding to original developments of capsule architecture from the 1960 s to 1970s and the resumed interest in capsule dwellings from 2000s.

Capsules are refered to 1960s' New Brutalism architectural style, which quickly lost its potential due to over-utopian nature ${ }^{14)}$. Moreover, the use of plastic as a building and finishing material having its breakthrough in 1956 was eventually shocked by Oil Crisis in 1973, giving simultaneously a formal end to capsules often made from different plastics for the next 30 years. In the period of

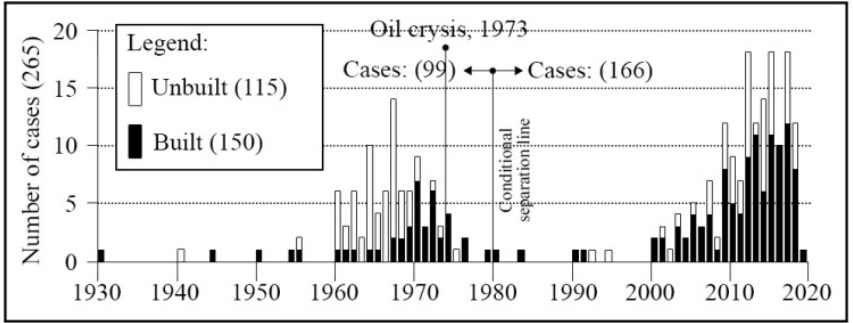

Fig. 3 Appearance of cases of capsule architecture 1980-1990 examples of modular architecture as well as the architecture which were afresh implying functionalism were rare. The beginning of the 2000s was already the time of grown environmentalist movement. Majority of cities in the developed world updated their waste and pollution regulations fusing the notion of future cities as sustainable environments with greener technology. A new practice of using shipping containers grew into large scale urban projects. Awareness of energy consumption affected both architects and citizens, and facilitated trend of sterile minimal lifestyle and movement from cities towards nature to small, prefabricated tiny houses for refreshment. Capsules of, what may be called 'a second generation' can have solar panels or compost as well as a chemical toilet to gain independence from urban systems and claim themselves as sustainable houses of the future.

\section{2 Concept of a capsule and its application}

Warren Chalk used the term 'capsule' in the project by Archigram called "Capsule Homes", 196415) and later Kurokawa fixed such name in his Capsule Declaration in 196916). Before, notions of 'living unit', or 'cell', or 'pod', etc., were also widely used. Senk describes an original capsule as an object which should fall into the following characteristics ${ }^{17)}$ : 1) relative impermeability of the envelope, 2) physical or simulated comfort of the introverted interior enabled by connection to the network, 3) structural, functional and visual integrity, 4) temporal conditionality or interchangeability, 5) smallness enabling movability or mobility. Container architecture or capsule hotels are discussed by Senk as derivations of the original concept ${ }^{18)}$ which originates from functionalist and experimental approach by several modernist groups. These practices aimed a reestablishment of a house and possibilities of environmental technology and creation of controlled environments 'fit' for living ${ }^{19)}$. Buckminster Fuller and his 'standard-of-living package' was one of the key examples of Banham's 'un-house' in the pursuit to find the 'other architecture'20) in contrast to the general trajectory of modernism. Similarly, the capsule homes by Archigram in the Plug-in city tried to reinvent the environment by "a series of very sophisticated and highly designed elements locked together... by large-scale industrial design approach" ${ }^{21}$. The original concept of a capsule is weaved into the search for 'other architecture' and later becomes more topical and independent. This concept transits to postmodernism and becomes mixed with notions of microdwellings and modular architecture.

Capsules show a range of properties that vary depending on the author, however, in general, can be summarized into the following major categories. Capsules are often compared to vehicles, which parts may be interchangeable, if only a part is broken ${ }^{22}$. Car itself is called by De Cauter as a mobile residence and extension of the house ${ }^{23)}$. Electric Tesla cars popular nowadays combine sustainability with interchangeability in their models blurring the definition of a car to, rather, 'self-driving functional places'. Another interpretation of a capsule is based on perceptions and acquisition of new experiences via the activity of an individual. Häusermann uses capsules as tools for people to express themselves as co-creators of the urban environment ${ }^{24)}$. Its modern analog - 'Shelter with Dignity' by Framlab is a social platform aiming to provide besides the shelter itself the dignity for people in need after they receive a residence as ordinary citizens ${ }^{25}$. Capsule architecture also serves as countermeasures to disasters or as social housing. The MDU (2003) by Lot-Ek is a modified shipping container similar to the expandable 'Tetrodon' unit from 1972 by AUA. The MDUs are supposed to be easily transported by sea as ordinary containers to other ports where they can be plugged in again to special shelves bearing dozens of the same units $^{26)}$. These examples play their role in the city metabolism by adjusting themselves to the current urban agenda. Therefore, the application of capsules may be divided into three following categories (Fig. 4).

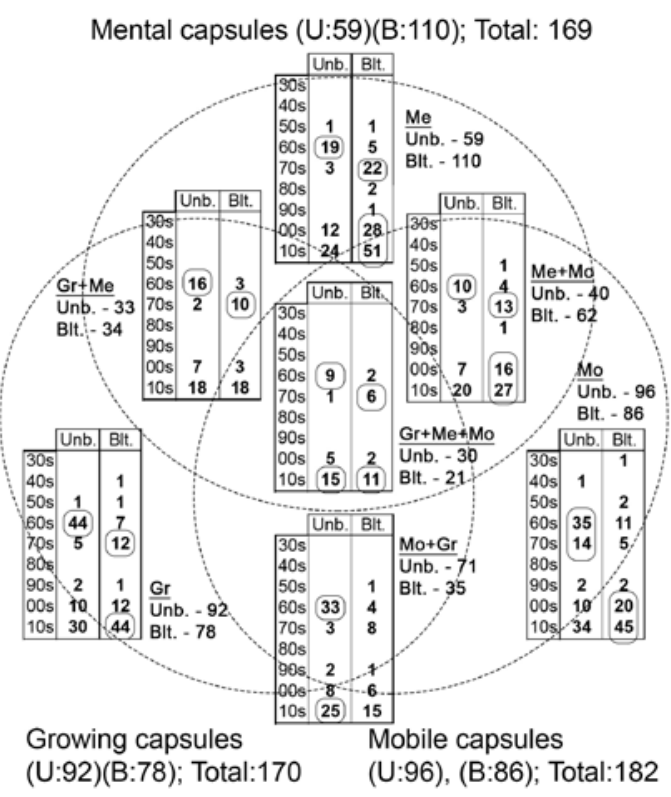

Fig. 4 Application of capsules 
Capsules utilizing mobility as their prior advantage; the capsules which are aimed to surpass the layer of either building codes of a country or any other paperwork connected to construction permits; and the capsules being financially affordable due to their lightweight and simplicity to assemble or dismount may be categorized into the 1st category - mobile capsules. The capsules which serve purposes as a shelter for mind, temporary loneliness or rest; the capsules which due to their closed nature create a different environment in order to isolate an individual from incoming information; and the capsules meant to symbolize innovation, joy of experimentation or provision of new impressions and experience are categorized into the 2 nd category - mental capsules. The capsules being viewed as a part of a capsule cluster what is able to change its shape, function division, organization and relationship between capsules in response to changing conditions; the capsules customized to be able to pile up onto each other as well as to a supportive core in order to create growing structures; the capsules allowing modification of themselves by fusion with each other; the capsules allowing clipping additional smaller premises to their own body; the capsules meant to be recyclable; and the capsules combined together and representing an independent urban object inside another medium are categorized into the 3rd category - growing capsules.

The division above is a separation of capsule's various applications which may be all-encompassing. Some capsules can be claimed by an architect as both a spiritual and mobile, or it can fall into all three categories. The iconic example of Nakagin Capsule Tower shows the capsules able to be movable, be replaced by capsules' exchange over time and provide the new lifestyle (urban nomadism). As it seen in the Fig. 4 there is an equal number of built and unbuilt cases except the category of mental capsules where built examples exceed twice in number. It can be said that this aspect of capsule architecture recently becomes topical. Also, all three application methods are equally often used by architects. Despite the fact that megastructures are out of the focus in modern architecture trends, some utopian projects continue a futuristic agenda. Moreover, the appearance of container architecture showed more flexibility how to decompose and recycle buildings with several successful projects (as Keetwonen or Spacebox capsules TU Delft).

\section{Basic characteristics of capsule architecture}

\section{1 Capsules and capsule clusters}

All capsules, in principle, prone to congregate in some structures what enhance their capacities. Thus, characteristics of capsule architecture may be divided into two groups: basic capsule characteristics as shape, function, material, and size, and the second group describing capsule clusters (i.e. capsular buildings) with number of capsules inside a single structure as well as a type of their arrangement (Fig.5). The basic physical characteristics of capsules and the structures which they create as well as their development in both built and unbuilt categories are summarized in Fig 6-11.

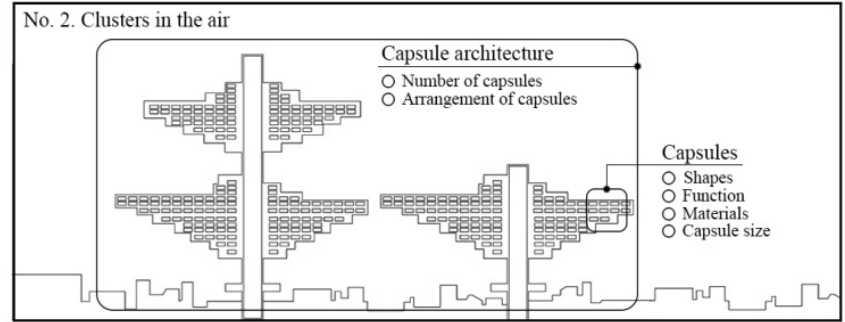

Fig. 5 Specification of characteristics of separate capsules and capsule architecture (Clusters in the Air, Arata Isozaki, 1962)

\section{2 Characteristics of capsules}

Capsules can be of different shapes unrestricted by own typology. However, capsules usually have to rely on connections to the neighboring capsules or supporting structures, which require a solid edge representing a wall or connection of a size of, approximately, a door between capsules. Fig. 6 represents a number and percentage of each shape in the total number of studied cases. The common shapes are: Rectangular (48,5\%), Custom shape (24,2\%), Cube (6,1\%), Polygonal (4,5\%), Tube (4,2\%), Sphere (3,8\%), Egg-shaped (3,8\%), Vehicle $(1,5 \%)$, and lastly Domes, Honeycombs, Cylinders and Hexagons as rarely occurring cases (3,4\% all together).

Despite the fact that capsules are usually monofunctional, the clusters which they create may be polyfunctional architecture as a whole. Capsule architecture is not limited to house provision and may allow using capsules for a different purpose and to be able to adjust and change functional content by rearranging capsules' roles or their contents. Fig. 7 represents the percentage of each function from the total number of studied cases. The percentages of each functions in both built and unbuilt categories are: Residential (46,5\%), Hotel room $(15,2 \%)$, Attraction (9,9\%), Multipurpose (9,6\%), Commercial space (5,7\%), Utilities (4,6\%), Office (3,9\%), and the capsules aimed to create Extensions of a house, Auditoriums or study rooms, Urban vertical farms and Sport facilities are the rarest examples (4,7\% in total). If compared to conventional buildings capsules' structures are often a monocoque structure or a similar bearing frame, to which various infill is applied. Capsules can consist of several components combined together to create an envelope. This section concentrates on primary materials from which the capsules are made from. It includes both materials for bearing structure and shells. It is not rare when a capsule's structure and walls are made from a single material. Fig. 8 represents the percentage of studied cases where each described material is shown. The distribution shows a gradual decrease in material use from 'plastics' to 'unspecified'. The category named 'unspecified' indicates the lack of information regarding materials in the given design that is omitted by an architect. So happens if a 
selected project is a concept, sketch or study which contains useful information about other properties of capsules, but lacks in clarifying materials' as a secondary characteristic ${ }^{* 4)}$. In the built category the 'unspecified' section is obviously zero. The percentage of each given material are: Plastics (32,8\%), Metal/Steel (17,6\%), Containers (17,2\%), Reinforced concrete shells (RC) (12,9\%), Wood (10,5\%), Unspecified $(4,7 \%)$, together with Concrete pipes, Glass (capsules mostly made from glass or designed to highlight glass material as a feature) as well as Other objects (besides shipping containers) (4,4\% in total).

Capsules appear in a variety of sizes. There are even capsules which fit inside a square of 2-meters side, while some capsules can include even several floors within its structure, and their longer side may exceed 10 meters ${ }^{* 5}$. Shapes of capsules vary drastically, especially those of a custom design. Therefore, it is confusing to correlate their actual size to only three spatial parameters. What can be alternatively done is to adjust a capsule's size to a cube with the defined dimensions in order to see if a capsule fits inside. This allows comprehensively evaluating an actual volume of a capsule as a set of various dimensions due to a capsule's shape. The Fig. 9 shows different capsules' sizes as follows: $2 \mathrm{~m}^{3}(14,7 \%), 3 \mathrm{~m}^{3}(22,6 \%), 4 \mathrm{~m}^{3}(16,6 \%), 5 \mathrm{~m}^{3}(11,3 \%), 7 \mathrm{~m}^{3}(29,1 \%), 10 \mathrm{~m}^{3}(4,2 \%), 20 \mathrm{~m}^{3}(1,5 \%)$.

\section{3 Characteristics of capsule clusters}

Capsule architecture is unique, and composition of capsules is not limited and may change over time. Nonetheless, the fact of natural 'shapelessness' of capsule architecture rises the question how to relate to capsules' count per single structure. In this research it is decided to count the current number of capsules in the built and unbuilt examples if the shape is conditionally and temporary determined by an architect (in the case of Nakagin Capsule Tower it is 140 capsules, despite the fact that in concept the building may grow to thousands of units)*6). Moreover, in the cases when a capsule is presented as a prototype and, in principle, the potential scale of expansion is undefined the capsule refers to the number ' $1+$ (no limit)'. Another note which should be clarified is the category named ' 1 '. This corresponds to some examples where a capsule is not meant to be mass-produced, but is chosen due to other characteristics, as simulated comfort, smallness, mobility, etc. Fig, 10 shows a number of capsules per single structure as follows: 1+(no limit) (31,5\%), 1 (8\%), 2-10 (16\%), 11-20 (11,3\%), 21-50 (13,9\%), 51-100 (6,3\%), 101-200 (3,8\%), 201-500 (3,8\%), 501-1000 (1,3\%), 1001 and more(4,2\%).

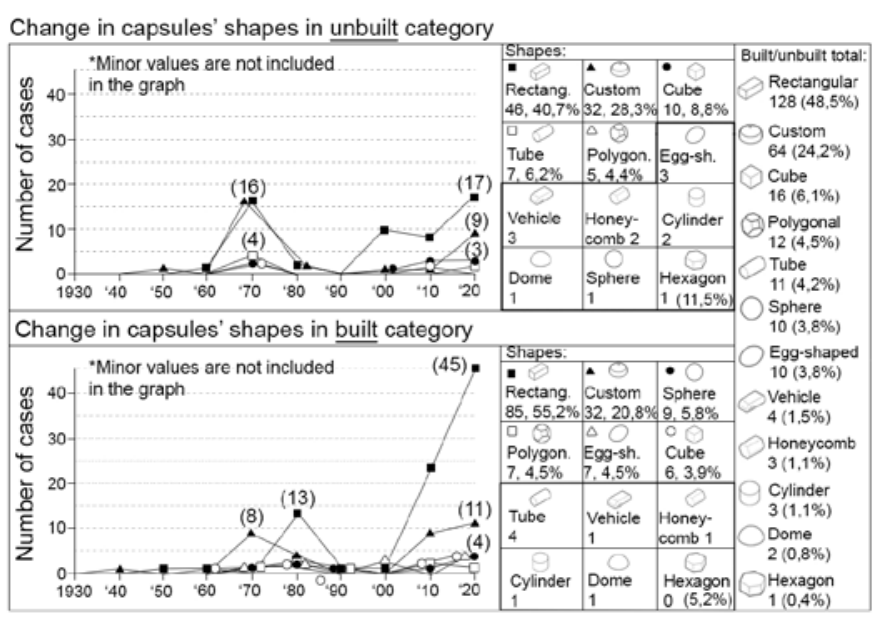

Fig. 6 Common shapes of capsules

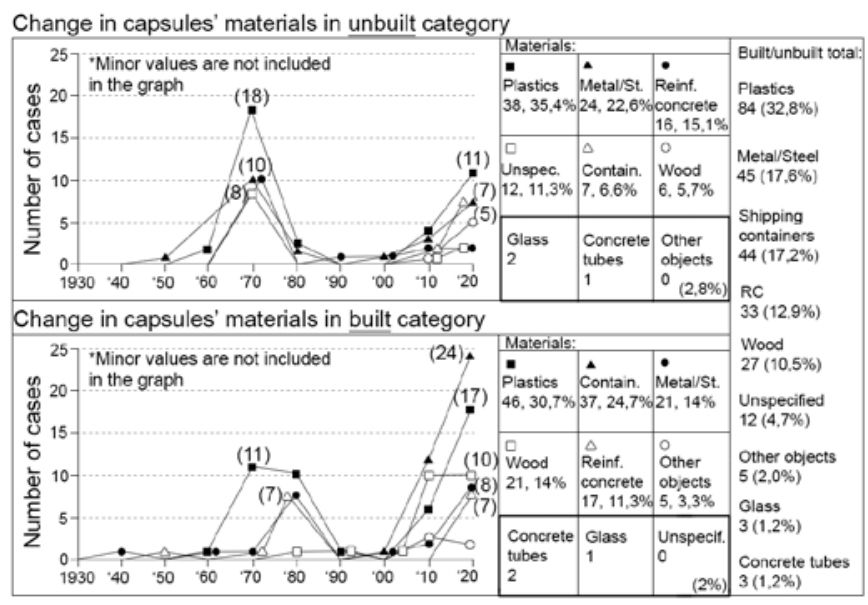

Fig. 8 Common materials of capsules

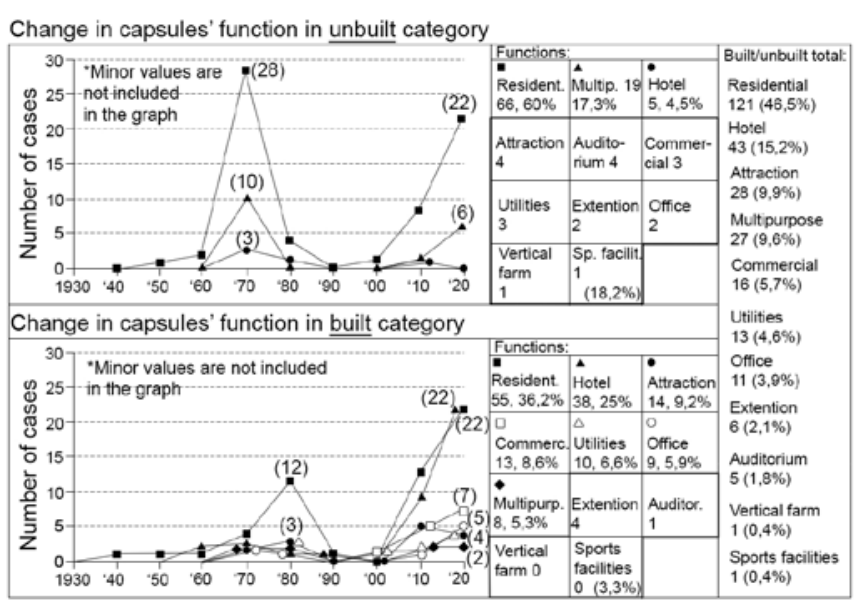

Fig. 7 Common functions of capsules

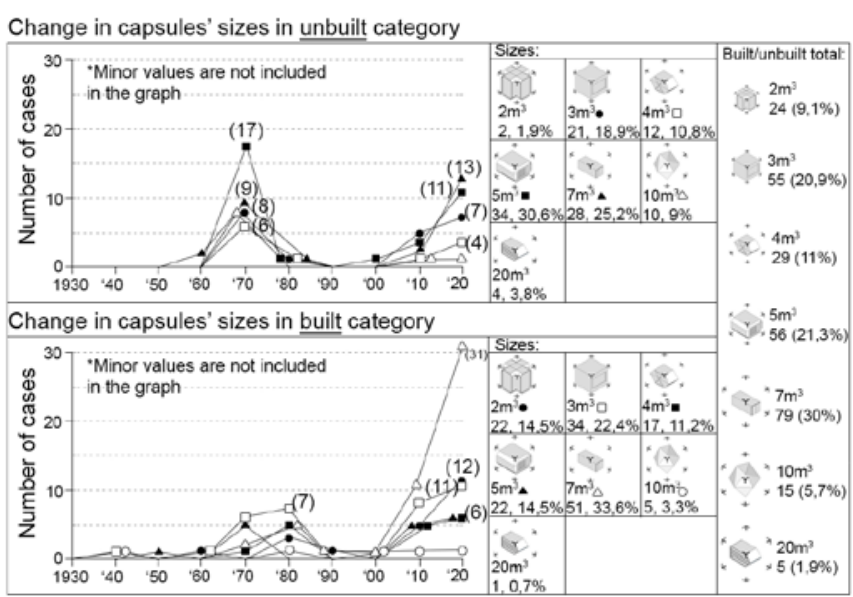

Fig. 9 Common capsules' sizes 
Change in number of capsules inside one building in unbuilt category

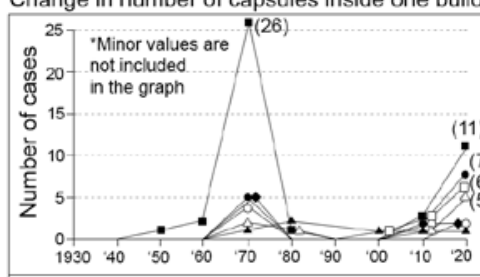

\begin{tabular}{l|l} 
Number: \\
\hline - 1 (no limit) & 1 \\
\hline $4,41,5 \%$ &
\end{tabular}

$2,2 \% \quad 1+$ no imit

\begin{tabular}{|l|l|l|}
\hline $2 \sim 10$ & $11 \sim 20$ & $731,5 \%)$ \\
\hline $6,5 \%$ & $4,4 \%$ & 1
\end{tabular}

(11)

\begin{tabular}{l|l|l}
$19(8 \%)$ \\
\hline
\end{tabular}

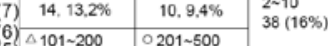

\begin{tabular}{l|l|l|}
$9.8 .5 \%$ & $8.7 .5 \%$ & $11-20$ \\
\cline { 1 - 2 } & $27(11,3 \%$
\end{tabular}

\begin{tabular}{|l|l|l|}
\hline $501 \sim 1000$ & $-1001+$ & \\
$2.2 \%$ & $7,6,6 \%$ & $21 \sim 50$ \\
\hline
\end{tabular}

$21 \sim 50$
$33(13,9 \%)$

Change in number of capsules inside one building in built category

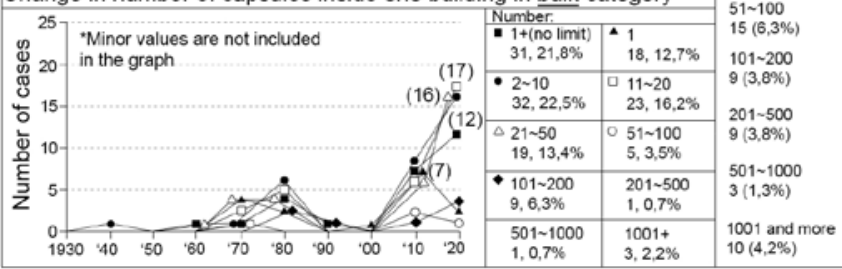

Fig. 10 Number of capsules inside a single structure
Tendency in methods of capsules' arrangement in unbuilt category

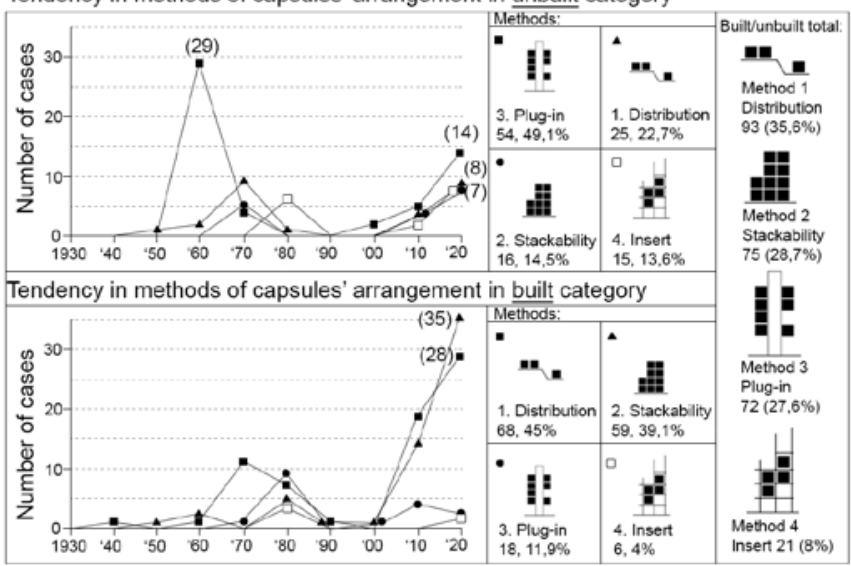

Fig. 11 Methods of capsules' arrangements

Capsules usually form complex structures with different kinds of relationship but they can be summarized in four basic ways ${ }^{* 7)}$ of arrangements. Two of them do not require supporting structure and two latter ways free capsules from structural loads. The Fig. 11 shows each method of arrangement as follows: Method 1 (distribution) (35,6\%), Method 2 (stackability) (28,7\%), Method 3 (plug-in) (27,6\%), Method 4 (insert) (8\%).

\section{Relationship between concept of capsule architecture and its application}

Initially capsules were closely related to postwar projects of megastructures serving as a tabula rasa for a community to form their own environments and individual living spaces - capsules ${ }^{27)}$. In the West it also coincided with the trends of consumerism, progressiveness and pursuit for the new spirit of time ${ }^{28)}$ while Japanese Metabolists, mostly focused on notions of the 'recreation' of the 'age of high metabolism'29). Despite being treated as inherent for modernist movement the capsules may have evolved into what can be called 'the second generation'. These capsules find their implementation in the examples of pop-up architectures, urban shelters, or entire green cities continuing the development of synthetic urbanism ${ }^{30)}$. Their role can be summarized in three major design topics - 'mobile', 'mental' and 'movable' capsules. The data shows even distribution of such approaches numerically and in both generations, what may indicate a common reoccurring interest towards the capsule's concept in general.

It reflects on capsule's objective characteristics, particularly shapes, sizes, and materials. While there is a stable trend of abandoning the plastic visage of a capsule, the strict rectangular shape continue combining in itself its ergonomic features in order to be mass-produced, moved in or out, and pile up in a cluster. Size of capsules varies - it both contributes to development towards the high-density living environment which is still topical in developing countries ${ }^{31}$, however there is a trend of small reduction of spatial capsules' sizes in the modern examples. Despite the obvious dominance of residential function in the conducted analysis, the hotel rooms and multipurpose capsules are also applicable to the same category (Fig. 7). Moreover, recent developments of container architecture and working business model of capsule hotels provide residence in extreme environments or cheap short stay combined with low-cost travelling.

Summarized by Leslie as a 'technological nihilism's2) the capsular structures can in principle grow indefinitely. Yet, the majority of capsular homes' designs in the 1960-1970s were left on paper. This experimentation continues in modern times, and some new startups present their vision onto small movable houses with the possibility to grow into bigger structures (Coodo, Loftcube, Kasita). Such developments, similarly to their predecessors, mostly position themselves as progressive hi-tech living environments. The modern capsular structures mostly do not implement any additional bearing elements or use the existing urban environment as a medium to be plugged-into or clipped-on. Despite the iconic example of Nakagin Capsule Tower where capsules are attached to the so-called 'vertical ground', the new image of capsular structures may be summarized in Container City (2001) consisting of shipping containers which could eventually gain the desired scale of mass-production multiplied with reusability, adaptability, and sustainability in order to be regarded as a modern capsule's archetype.

\section{Conclusion}

In overall capsules may be divided into two generation corresponding to increased number of capsular designs in the 1960s and also recently. The dashing development of technology and industry together with trends of sustainability and flexibility entrusted to the modern cities would influence the future urban environment as never before even considering the inertia of construction methodology evolving slowly. Yet, completely capsular cities will, probably, remain mostly inside the conceptual realm. Opposite to the drastic change of 
urban matter proposed by many architects in the 20th century, nowadays the cities are thought to gradually tune themselves into more eco-friendly, resilient entities while the capsules will serve their new duty inside the current trend of sustainability by the provision of nomadic closed spaces, moveable spaces, pop-up architecture, housing for the unprotected social stratum, and temporary dwellings. The understanding of properties of such architecture will allow creating the buildings of higher quality. And another important question that capsule architecture raises is the temporality of buildings which have their defined lifespan. Therefore, architects may give consideration about the life and eventual physical death (demolition) of their architecture, or, on the opposite, its renovation into something what fits current time and purpose. In a sense, this is also sustainable architecture.

\section{Reference}

1) Lin Z: Nakagin Capsule Tower and the Metabolist Movement. Revisited. 98th ACSAAnnual Meeting Proceedings, Rebuilding, pp.514-518, 2010

2) Lin Z: Nakagin Capsule Tower and the Metabolist Movement. Revisited. 98th ACSA Annual Meeting Proceedings, Rebuilding, pp.515, 518, 2010

3) Hosoya H. and Schaefer M.: Tokyo Metabolism, Project On The City 2, Taschen, 749, 2001

4) Sugai T., Yokote Yo.: Study on the Sustainability of Nakagin Capsule Tower Building in Kisho Kurokawa's Metabolism thought, Summaries of Technical Papers of Annual Meeting, Architectural Institute of Japan, History and Theory of Architecture, pp. 757-758, 2014. 7 (in Japanese)

菅井 隆史, 横手 義洋:黒川紀章のメタボリズム思想と中銀カプセルタワービルの現状, 日本建築学会大会学術講演梗概集, 建築歴史・意匠, pp. 757-758, 2014. 7

5) Koolhaas et al.: Project Japan, Metabolism Talks, Taschen, 19, 2011

6) Kurokawa K: Oh! The Code of the Cyborg, SD-Space Design 03/1969, 50 (in Japanese)

7) Hidaka J.: Nakagin Capsule Tower, UIA 2011 Tokyo Design 2050, pp.16-17, 2011 (in Japanese)

8) Schalk M.: The Architecture of Metabolism. Inventing a Culture of Resilience, Arts 3, 279, 2014

9) Russell S.: Metabolism Revisited: Prefabrication and Modularity in 21st Century Urbanism, Without a Hitch - New Directions in Prefabricated Architecture, 253,2008

10) Russell S.: Metabolism Revisited: Prefabrication and Modularity in 21st Century Urbanism, Without a Hitch - New Directions in Prefabricated Architecture, 247, 2008

11) Lemes de Olivera F. Of Metabolism: future cities for our contemporary world, NSCO 14, 77, 2011

12) Pernice R.: Metabolism Reconsidered. Its Role in the Architectural Context of the World; Journal of Asian Architecture and Building Engineering, 357, November 2004

13) Senk P.: Capsules. Typology of other architecture, Routledge, 182, 2017

14) Senk P.: Capsules. Typology of other architecture, Routledge, pp.28-39, 2017

15) The Archigram Archival Project: Capsule Homes project, project No: 62, http://archigram.westminster.ac.uk/project.php?id=58 (accessed 2020.12.24)

16) Kurokawa K.: Metabolism in Architecture, Capsule declaration, Westview Press, pp.75-85, 1977

17) Senk P.: Capsules. Typology of other architecture, Routledge, 5, 2017

18) Senk P.: The Concept of Capsule Architecture as Experiment, Prostor, 352, 2.46, 2013.21

19) Langevin J.: Reyner Banham: In Search of an Imageable, Invisible Architecture, Architectural Theory Review 16(1):2-2, 8, 2011

20) Langevin J.: Reyner Banham: In Search of an Imageable, Invisible Architecture, Architectural Theory Review 16(1):2-2, 7, 2011

21) The Archigram Archival Project: Capsule Homes project, project No: 62, http://archigram.westminster.ac.uk/project.php?id=58, (accessed 2020.12.24)

22) The Archigram Archival Project: Capsule Homes project, project No: 62, http://archigram.westminster.ac.uk/project.php?id=58, (accessed 2020.12.24)

23) De Cauter L. and Patteeuw V.: The Capsular Civilization: On the City in the Age of Fear, NAi Publishers, pp.78-79, 2004

24) Frac Centre-Val de Loire, Pascal Häusermann, http://frac-centre.fr/collection-art-architecture/rub/rubauteurs-58.html?authID=87 (accessed 2020.12.24)

25) Framlab, Shelter with Dignity, https://.framlab.com/homed (accessed 2020.12.24)

26) Lot-Ek, Mobile Dwelling Unit, https://lot-ek.com/MDU-Mobile-Dwelling-Unit (accessed 2020.12.24)

27) Senk P.: The Plug-in Concept: Technology and Aesthetics of Change, Architecture, Research, 44, 2013/1

28) Senk P.: The Concept of Capsule Architecture as Experiment, Prostor, 352, 2.46, 2013.21

29) Schalk M.: The Architecture of Metabolism. Inventing a Culture of Resilience, Arts 3, 283, 2014

30) Senk P.: The Plug-in Concept: Technology and Aesthetics of Change, Architecture, Research, 48, 2013/1

31) Lin Z: Nakagin Capsule Tower and the Metabolist Movement. Revisited. 98th ACSA Annual Meeting Proceedings, Rebuilding, 520, 2010

32) Leslie T.: Just What Is It That Makes Capsule Homes So Different, So Appealing? Space and Culture 2006, 9, 180, 2006

Notes

*1) The term 'megastructures' is usually fixed to Metabolists, although there are different names as 'superstructures' or 'macrostructures' representing an enormous three-dimensional urban infrastructure with no architecture but a combination of functional spaces, living units, roads, etc. Dahinden J.: Urban Structures for the Future, Praeger Publishers, pp.14-18, 1972

${ }^{*} 2$ ) "The concept of the capsule, explicitly naming compact, minimal, completely furnished and equipped living units, has generally been presented in architectural history in relation to the trend of megastructures and utopian radical architectural experiments with uncritical faith in technological and scientific progress of the 1960s", Senk P.: The Concept of Capsule Architecture as Experiment. Origins and Manifestations with Selected Examples from Slovenia and Croatia, Prostor, 352, 2.46, 2013.21

*3) Datinhen would usually call a 'container' the entire urban structure with rigid borders, simulated comfort inside or how the author himself put it “containers of human activities' long before the first housing projects utilizing containers occur. Dahinden J.: Urban Structures for the Future, Praeger Publishers, 8, 1972. Senk P.: Capsules. Typology of other architecture; Routledge, 6, 2017

*4) Despite the fact that some studied cases might have are labeled 'unspecified' in this research, the number of cases in 'unspecified' category may not have a noticeable influence on the received results.

*5) See projects by Kenji Ekuan - Dwelling city (1964) and World of chlorophyll by IAMZ Design Studio (2012)

*6) Also, it is not excluded that an architect may utilize an unfinished appearance of a building and potential of growth as a tool for architectural expression.

*7) This separation is based on Senk's classification of the capsules as: method 1 - 'independent cells', method 2 - 'composite cells', method 3 'clip-ons/plug-ins, parasites', method 4 - 'pendants, inserts'. Senk P.: Capsules. Typology of other architecture, Routledge, pp.114-146, 2017 
Appendix 1. Selected examples
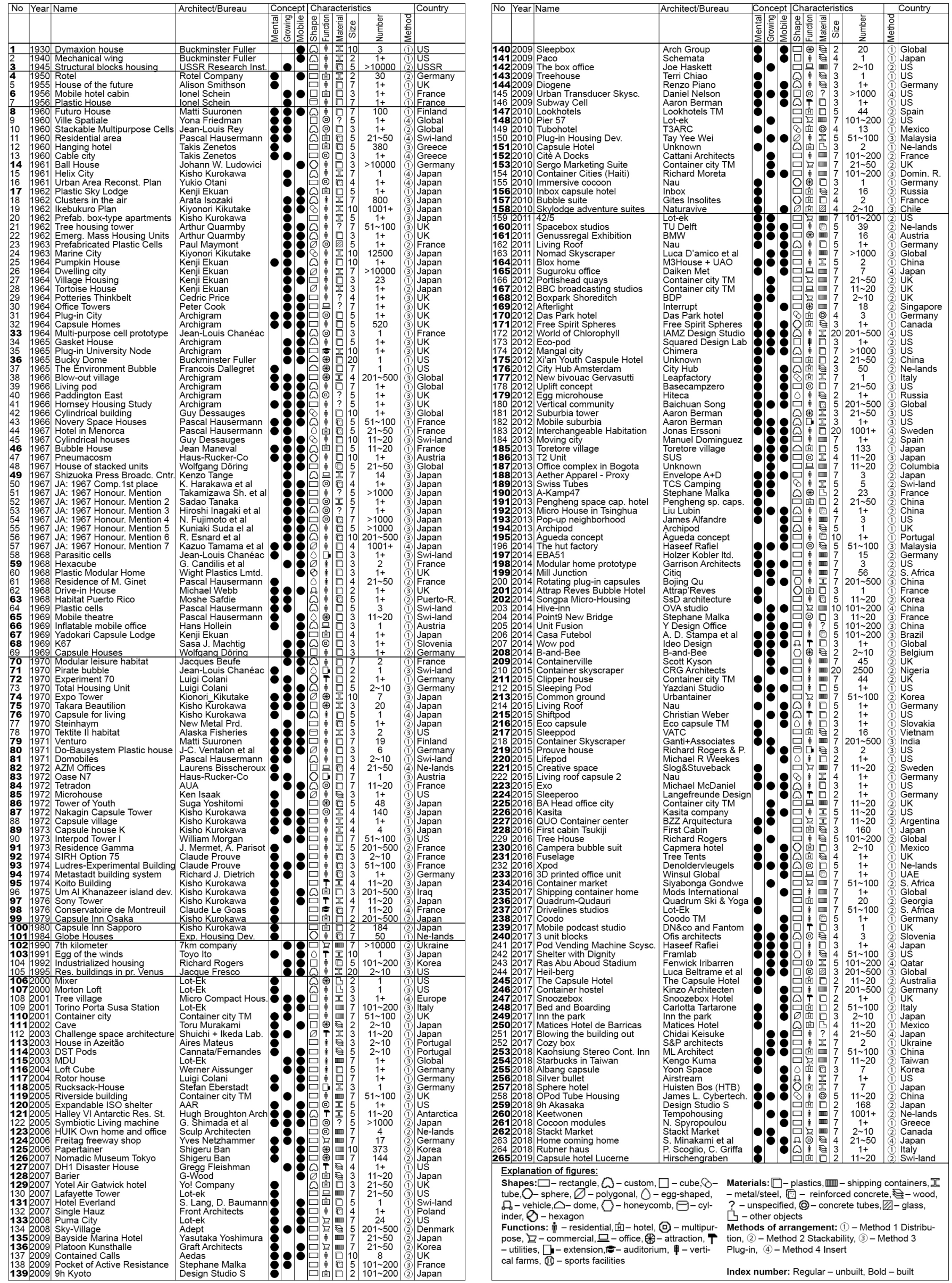


\section{Summary in Japanese}

本論文は、世界各国で設計されてきたカプセル建築の基礎的研究として、それらの特徴を総体的に検討するものである。まず、先行研究に基

づいてカプセル建築を定義し、最初期の事例と考えられるモダニズム期の 1930 年から、現代に至るおよそ 1 世紀弱の期間において 265 の事例

（非実現プロジェクト含む）を蒐集し、それらが 1960 年代前後と 2010 年代前後の 2 つのピークに集中して設計されていることを見出してい る。その上で、カプセル建築の設計主題を検討し、それらを「可動性 (mobile)」（カプセルが動かせることに重点を置く主題）、精神性 (mental)」 (閉じたカプセルの内部での経験やそれに関する感覚、新しい精神性に重点を置く主題)、そして「拡張性（growing）」（カプセルを増減できる ことに重点を置く主題）の 3 つの主題とその組み合わせで整理できることを述べ、さらにそれらカプセルの形状、機能、素材、サイズ、個数、 またカプセル建築の構造を基礎的検討として通時的に整理している。

カプセルの実体的特徵としては、長方形の形状、住宅機能、金属とプラスチックの素材、 $3 \mathrm{~m}^{3}$ から $7 \mathrm{~m}^{3}$ のサイズが相対的に多いことが分かっ た。カプセルのサイズについては、カプセルが構造的に他のカプセルに繋がれることにより特殊な形状（例えば関節部、コンソール部、脚部な どをもつ形状）をもつことから、見た目のサイズと内部空間のサイズに齟龉が生じることが散見された。カプセルが単一の構造をもつ場合、実 現プロジェクトではカプセル数が 50 ユニットを超えない傾向があり、一方、非実現プロジェクトでは、カプセル数が数千のユニットからなる 事例もみられ、さらに都市全体まで拡張できるとする壮大なプロジェクトもみられた。カプセルの配置については、「(1)地形上に広がる」、「(2) 積み重ね」、「(3)プラグイン」といった方法が多くみられ、「(4)構造グリッド内に挿入」が最も稀なタイプだと分かった。

以上の検討は、カプセル建築の構想・設計における設計主題と実体的特徵を総体的に把握・検討したもので、今後のカプセル建築の研究のた めの基礎的な研究として位置づけられると考える。

\section{Summary in English}

This paper concentrates on the concept of capsule architecture and its application. The study uses the definition of a capsule provided by previous studies as a basis and follows the common trend of reevaluation modernist practices with the focus on capsular designs from the 1930s and their modern successors. The paper aims to create a comprehensive view of the history of the development of capsule architecture and supports the idea of the continuous nature of such development. In order to achieve this study collects 265 cases of capsular buildings as well as separate capsule examples and inspects them from different aspects to observe major trends. The research showed that the concept of capsule architecture, despite being interpreted by architects in different ways, usually falls into three main categories which can be named 'mental', 'growing', and 'mobile' capsules. Some capsules' design can utilize all of these categories, and, in principle, be claimed by an architect as a universal and flexible architectural tool. Also, the concept's application directly reflects on capsules' basic characteristics namely shape, function, materials, size, number of capsules per structure, and method of capsules' arrangements. This helps to better classify capsules depending on their application and construct a capsule's common image. Therefore, a capsule generally can have a rectangular and various custom-made shapes, bear mostly residential function, made of plastics or metal, and has a size of approximately fitting inside 3 to $7 \mathrm{~m}^{3}$ cube chosen as a tool of measurement due to a big number of custom-made shapes where it is difficult to obtain correct measurements. This is partly because capsules can have a shape allowing conglomeration with similar units, so a capsule can have joints, consoles, legs, etc. If capsules form a single structure, in the built examples this number tends not to exceed 50 units, while in the unbuilt section this number is more spread among different scales of capsular structures able to grow to thousands of units and entire capsular cities. Lastly, the method of capsules' arrangement already well defined by previous studies and is as follows: (1) the capsules spreading on topography, (2) stackable, (3) plug-in, and, notably, (4) the capsules inserted inside a grid and which are the rarest type. The general characteristics of capsules allow demonstrating the common image of a capsule as a phenomenon in the architectural realm and showing the potential and usefulness of capsular designs over conventional architecture and serve as a basis for the further research onto capsule architecture. 